\title{
A strategy for the management of HIV/ AIDS in the health sector of the city of Johannesburg
}

\author{
A Barnard, Masters student, Nursing Department, RAU \\ M Muller, DCur, Professor of Nursing, Nursing Department, RAU
}

\section{Abstract}

The HIV/AIDS pandemic is posing major challenges to all sectors in South Africa, including the health sector of the city of Johannesburg. The health sector of the city of Johannesburg, as a result of the pandemic, is faced with increasing demands on its scarce resources at a time of major reform at local government level including transformation of the health sector. The overall objective of the study is to explore and describe a strategy for the management of HIV/AIDS by the health sector of the city of Johannesburg. An exploratory, descriptive and quantitative research design was utilized and the UNAIDS "Guide to the strategic planning process for a national response to HIV/AIDS" (1998), was employed to formulate the strategy. The content validity of the strategy was determined according to the process originally described by Lynn (1986) and adopted by Muller (in Booyens, 1998:607-609). The research was conducted in two phases. The first phase, the developmental phase, involved the exploration and description of the theoretical framework and the response to the pandemic, and formulation of a draft strategy. The second phase, the quantification phase, involved the assertion of the content of the strategy by a group of experts and determination of the content validity index (CVI). The final strategy focused on the following: to lead and facilitate intersectoral collaboration; to strengthen primary health care services to provide comprehensive communitybased care; prevention of new infections; community mobilization towards prevention, non discrimination and non stigmatization and empowerment of the health sector to deal with the AIDS pandemic. The CVI results showed that the average content validity index determined during this study was adequate: full score (1.0) for acceptability and technical soundness, and 0.89 for feasibility and perceived affordability. The strategy formulated for the management of HIV/AIDS by the health sector of the city of Johannesburg is therefore acceptable, technically sound and feasible and perceived as affordable. It was finally recommended that the strategy be adopted for implementation within the health sector of the city of Johannesburg.

\section{Introduction}

South Africa is currently faced with the fastest growing HIV/AIDS pandemic in the world. It is estimated that at the end of the year $2000,4.7$ million out of an estimated population of 43 million South Africans were infected with the Human Immuno Deficiency Syndrome (HIV) which inevitably causes Acquired Immune Deficiency Syndrome (AIDS) (Department of Health, 2001a:19). Since the introduction of the annual national HIV/AIDS survey of women attending public sector antenatal clinics in South Africa, the HIV/ AIDS prevalence rates have increased from $1.49 \%$ in 1991 to $24.8 \%$ in 2001 . The survey also revealed that in the central Witwatersrand region, constituting the city of Johannesburg, the prevalence rate was $29.8 \%$ among women attending public sector antenatal clinics (Department of Health, 2001a:8). An impact analysis conducted for the city of Johanneshurg estimated that 168921 HIV infected per- sons were living in the city of Johannesburg in the year 2000 (City of Johannesburg, 2001:21). Among the higherrisk groups such as persons availing themselves for the treatment of sexually transmitted infections (STIs), the recorded HIV/AIDS sero prevalence rates were recorded even higher, at $53 \%$ for female and $35.8 \%$ for male persons (South African Institute for Medical Research, 20(0): I).

The inhabitants of the city of Johannesburg are particularly vulnerable to HIV/AIDS infection because of the of job prospects that tend to lure migrant labourers from the whole of Africa to the city, the transport infrastructure of the area, the high levels of mobility of the community, the existence of single sex hostels, marginalized communities living in informal settlements, income inequality and poverty. Other aspects increasing vulnerability applicable to the circumstances in the city of Johannesburg include the disruption of family and communal life resulting from apart- 
heid and the migrant labour system, very high levels of other STIs, the low status of women in society and in relationships, social norms that accept or encourage high numbers of sexual partners and resistance to condom use (Smart. 2(0)1:6).

The high HIV/AIDS prevalence rates and social circumstances peculiar to the city of Johannesburg strongly stress the threat of HIV/AIDS to the inhabitants of the city of Johannesburg. Since the local government elections in December 2000 the management of the city of Johannesburg has introduced a process of mayor restructuring. The new council of the city of Johannesburg has identified HIV/ AIISS as a threat and has prioritized HIV/AIDS as one of the six strategic priorities (City of Johannesburg, 200) : 2; 34). A strategic plan, in coherence with the plans at national and provincial governments, that would guide the management of the health sector of the city of Johannesburg, will enable the sector to anticipate the impact of the pandemic, to be situation-specific in getting to the root of the problem, and would result in moving towards a situation where HIV spreads less rapidly and has fewer negative consequences for those infected. and for their families and society.

The following research question is relevant: What strategy should be adopted by the health sector of the city of Johannesburg to manage the HIV/AIDS pandemic in the futured The purpose of the study is to explore and describe a strategy for the management of HIV/AIDS by the health sector of the city of Johannesburg.

\section{Terminology}

\section{HIV/AIDS}

AIDS is a severe, life-threatening clinical condition that represents the late clinical stage of infection with the human immunodeficiency virus (HIV), which most often results in progressive damage to the immune and organ systems, including the central nervous system (Benenson, 1995:1).

\section{Pandemic}

A pandemic is an epidemic that spreads over a widespread geographical area.

\section{A strategy}

A strategy is a series of steps designed to move from one situation to another. The steps in strategic planning will be defined in terms of the programmes or initiatives that will carry the country or district from the current situation towards realising the objective. A strategy is thus made up of a series of steps, each of which creates a new situation in a gradual march towards the objective (UNAIDS, 1998: 12).

\section{Primary Health Care as delivered by the health sector of the city of Johannesburg}

The core business of the city of Johannesburg is the delivery of Primary Health Care (PHC) services. Buch (2000:4) refers to Primary Health care as non-hospital care provided through health centres and clinics and in the community. It is commonly divided into personal and environmental health, both of which engage in prevention of health problems and promotion of health, care and rehabilitation.

\section{Research design}

An exploratory, descriptive and contextual research design was utilized (Burns \& Grove, 2(0)1:43-52; 249; Brink, 1996:11), consisting of a developmental and a quantification phase. The development of the strategy was based on the process applied to strategic planning for a regional/national response to HIV and AIDS as described by the United Nations (UNAIDS, 1998), consisting of the following steps: situation analysis, response analysis, strategic plan formulation and resource mobilization. The situation analysis is based on the exploration and description of the following: factors that may be relevant to HIV and AIDs; factors that favour or impede its spread; factors that favour or impede achieving the best quality of life for the affected and infected; international, national and provincial strategies; the legal framework, issues of local importance, the stakeholders and the underlying dynamics (UNAIDS, 1998:1-4). The response analysis seeks to determine the best practice through a literature review of best practice. It also considers programmes and initiatives that are succeeding or failing, the potential opportunities and obstacles by conducting strategic sessions with internal and external stakeholders. A gap analysis is then conducted to identify the gaps in the response to the pandemic and in consideration of the outcome of the situational analysis (UNAIDS, 1998:6).

The following data collection methods were utilized during this phase of the study:

- Literature survey/text analysis: an exploration, description and analysis of the situation, international, national and provincial strategies, the legal framework. and a description of issues of local importance, best practice principles, the stakeholders and dynamics

- Document analysis (national, provincial and local policies, surveillance data, strategic plans, best practice standards, etc)

- Consultative workshops with different stakeholders/ roleplayers (refer to population and sampling) focusing on the following (UNAIDS, 1998:2-4): what is working and needs to be continued (strengths); what is not working and requires a new transformative approach (weaknesses); what is working but needs to be expanded upon (opportunities); what is not relevant to current needs and should be dropped (threats) and what has not been addressed at all (gaps)?

- Individual consultative interviews with managerial stakeholders/ roleplayers.

The draft strategy is subsequently formulated, focusing on the following steps UNAIDS, 1998:13):

- Re-examination of the national guiding principles 
- Setting of goals in the priority areas

- Development of strategies to attain the goals

- Development of the strategic framework

- Examining the strengths and weaknesses of the proposed strategies

- Revising the goals/objectives if necessary.

The strategy was drafted (refer to results). This was followed by the determination of content validity of the strategy, based on the process originally described by Lynn (1986) and adopted by Muller (in Booyens, 1998:607-609): exposure of the draft strategy for critical debate and judgment by domain experts and appropriate roleplayers, relerred to as appraisors/validators, focusing on the following: acceptability of the strategy, technical soundness and teasibility and perceived affordability (UNAIDS, 1998). The nominal group technique was utilized (Muller, 2002:173):

- A formal interactive decision-making technicue

- Consisting of group members with nominal (the same) interests and attributes pursuing a common goal (in this case the critical judgement/validation of the draft strategy)

- The contributions of the group members are made in an organized and non-threatening manner

- Group members give their critical judgment inputs in a round-robin fashion, followed by critical and focused debate of all the group members, with final consensus as to what CVI rating (yes/no) should tinally be allocated to the particular dimension of the draft strategy.

The principle of sufficient consensus reached by the appraisors/validators during the critical debate and judgement of content validity during this phase, was applied (Muller, 1998:608-609). The draft strategy was reflected in a structured questionnaire format, consisting of the following: information on the appraiser/validator with reference to representation and domain expertise, the dimensions of the draft strategy rellected in the form of a check list (yes/ no) with reference to acceptability, technical soundness and feasibility, as well as the perceived affordability (UNAIIDS, 1998:16).

A descriptive frequency distribution was analysed and the mean "yes" rating by the validators for each dimension of the draft strategy was determined which was reflected as the CVI. The maximum group size of the validators was ten, as recommended by Lynn (1986:384) and Muller (in 1998:608). The CVI is based on a sliding scale: 1,() equals ten members allocating a "yes"; 0.90 equals nine members confirming the validity with a "yes", etc. According to this proportional sliding scale, at least seven members should confirm the validity of the specific dimension to be accepted as sufticient consensus.

\section{Population and sampling}

The research population consisted of both internal and external stakeholders within the city of Johannesburg with reference to primary health care service delivery. They were the members of stalf within the health sector of the city of Johannesburg who account for the implementation of the strategic plan. The positions included the director health services, deputy director(s) programmes, sub-district health directors, managers and operational managers, staff directly involved with HIV/AIISS services, as well as the HIV/AIDS co-ordinators. Provincial internal stakeholders were also included in the population: directors. deputy directors and assistant directors at the Gauteng Provincial Regional office Region A and regional HIV/AIDS co-ordinators.

The external stakeholders were 24 funded organizations: the non-governmental organizations (NGOs), communitybased organizations (CBOs) and faith-based organizations (FBOs). The Johannesburg AIDS Council represents these organizations. Other groups included in the population are the persons living with HIV/AIDS (PWAs) and those affected by the disease.

A purposive non-probability sampling method was utilized (Burns \& Grove, 2(0) 1:374-375). Roleplayers/stakeholders and domain experts were identified by the researcher, in consultation with members of management, based on the following inclusion criteria within the context of the health sector of the city of Johannesburg:

- The researcher defines "experts" as those persons who will be responsible for the implementation of the strategy, adherence to the key performance indicators and time frames:

- Members that have a formal full time and permanent appointment in the positions described in the population

- Members that would be available to participate in the scheduled consultative workshops

- Representation from all stakeholder groups was ensured, utilizing the principle of quota sampling (Burns \& Grove, 2(x)1:375).

\section{Reliability and validity}

The following control measures were applied to ensure validity and reliability of the strategy (Thomson, 1997:18519.3):

- Appropriate selection of the stakeholders/ roleplayers in both the developmental phase (drafting of the strategy during consultative workshops) and the validation of the strategy to ensure adequate expertise, ownership and representation of all stakeholders/roleplayers

- Participants were given equal opportunity to participate in the consultative workshops and the validation phase when the nominal group technique was applied

- Theoretical validity is based on the application of a comprehensive process, as described by the UNAIISS (1998).

- A formalized process was followed to draft the strategy and to determine the content validity of the 
strategy.

\section{Ethical considerations}

The ethical standards for research, as set out by the Democratic Nursing Organization of South Africa (DENOSA, 1998) were adhered to in this research. The researcher obtained written, informed consent from the relevant authority to conduct the research and participants were informed of the status and objectives of the research, type and method of data collection, and possible benefits to the authority and the participant. Due to the sensitive nature of HIV/ AIDS participants were informed that they may withdraw from the study at any time they wish (especially participants living with or affected by HIV/AIDS).

\section{Results}

The draft strategy was formulated, based on the following dimensions (see figure one):

- To lead and facilitate intersectoral collaboration

- To strengthen primary health care services to provide comprehensive communit-based care

- $\quad$ Prevention of new infections

- Community mobilization towards prevention, non discrimination and non stigmatization

- Empowerment of the health sector to deal with the HIV/AIDS pandemic.

A total of two consultative workshops were held and thirteen participants attended the workshops. Individual interviews were conducted with two internal stakeholders representing managerial positions (refer to population). Two sessions, utilizing the nominal group technique (Muller, 20()2:173) were held to determine the content validity of the draft strategy. Ten and nine participants (domain experts) appraisors/validators rated the draft strategy respectively.

The draft strategy was confirmed as valid. The average Content Validity Index (CVI) determined, was 1,0 for acceptability and technical soundness (all ten participants in both workshops confirmed the content validity) and 0.89 for feasibility and 0.89 for perceived affordability. Therefore, a high Content Validity Index (CVI) with reference to acceptability and technical soundness was obtained.

\section{Theoretical framework}

The theoretical framework was developed, based on local, provincial, national, as well as international principles and criteria for the management of HIV/AIDS, in relation to the context. objectives, stakeholders, the process/strategy and underlying dynamics. This process entailed a situational analysis, followed by a response analysis, in accordance with the process of strategic planning for the management of HIV/AIDS (UNAIDS, 1998). Many local, provincial/regional, national and international resources were utilized (AIDS Directorate, 200); Buch, 2000); City of Johannesburg, 2001 ; Department of Health 2000a,b,c; Department of Health, 2001a,b; Drysdale, 2001; Education and Training
Unit, 2001; Evion et al., 2000; Floyd \& Simon, 1999 and 20(0); Gauteng AIDS Directorate 1999a,b,c; 2002; Gauteng Provincial Government. 20()1; Greater Johannesburg Metropolitan Council, 1999; Harley, 2000); Intersectoral AIDS Unit, 20()1: Johannesburg HIV Management Services, 1998; Karim et al., 1997; SAIMR, 20(0); Smart, 200) ; UNAIDS, 1999; Wilson, 2000; World Bank. 1999).

\section{Situational analysis}

The strategy is developed for the city of Johannesburg in Gauteng. A situational analysis was conducted with reference to the factors relevant to HIV, factors that favour or impede the spread of HIV and factors that impede of favour achieving the best quality of life for those living with HIV and the affected. International, national and provincial strategies, within the professional, ethical and legal framework, were analysed and described. Issues of local importance, such as the demographic profile of the city of Johannesburg, economic profile, human resource development, safety and security were assessed. Both the internal and external stakeholders involved in a strategy for the management of HIV/AIDS, were identified. The internal and external dynamics that could possibly impact the strategy, were also deleniated. The concluding statements, based on this analysis, are as follows:

- $\quad$ High levels of HIV/AIDS prevalence were noted within communities of the City of Johannesburg. particularly among the highly vulnerable population groups. HIV/AIDS is a definite threat to the capacity of health services and the socio-economic development of the city. The reasons for the high levels of prevalence are factors characteristic to the City of Johannesburg driving the pandemic.

- $\quad$ The factors favouring the spread of HIV include high levels of sexually transmitted infections (STIs) and mother-to-child-transmissions (MTCT), high rates of prostitution, gender discrimination, women and child abuse and occupational exposure to HIV. The spread of the disease is being impeded by ( voluntary counseling and testing (VCT), health education and condom distribution. Factors favouring achievement of the best quality of life to those affected and infected include the delivery of PHC services, counseling and home based care.

- The international, national and provincial strategies indicate that political commitment is the key to addressing the problem of AIDS. Political commitment to fight the pandemic/epidemic has been observed and has become evident in the recently appointed AIDS Council and the prioritizing of the disease on the Council's agenda.

- Common trends in both national and provincial strategies are the prevention of new infections in order to reduce the incidence, the provision of care to those infected and affected to promote their quality of life and reduce the socio-economic impact and the development of monitoring and evaluation systems. These issues also became part of the major strategic thrusts employed by the strategy for the 
city of Johannesburg. The goals of the strategy compiled for the city are to lead and facilitate intersectoral collaboration; to strengthen primary health care services and provide comprehensive community based-care, prevention/reduction of new infections and community mobilization towards prevention, non discrimination and non stigmatization and capacitate the health sector to deal with the AIDS epidemic/pandemic.

- Intersectoral collaboration and development of programmes at local-government level are key focus areas of the provincial strategy pointing to the need for a strategic focus on HIV/AIDS by the local government. The role of various stakeholders is acknowledged, whilst the key role of co-ordinating these stakeholders to maximise the joint response to the epdemic/pandemic is identified. It should be noted, as has been mentioned, that one of the goals formulated for the strategy is to lead and facilitate intersectoral collaboration.

- The health sector is leading the response to the pandemic according to the stipulations of the Health Act (South Africa, 1977, as amended). This act requires local government to prevent the spread of diseases, promote health and deliver curative and rehabilitative services. The White Paper for the Transformation of the Health System in South Africa, 1997, affirms the principles for HIV/AIDS prevention, treatment and care (Department of Health, $2000 \mathrm{~b}: 17-18)$. These principles were taken into consideration during the drafting of the strategy.

\section{Response analysis}

A response analysis was conducted (UNAIDS, 1998), focusing on local, provincial/regional and national studies in relation to the principles of best practice, performance audit and gap analysis. The best practice analysis focused on the following: the management of sexually transmitted infections (STI's), condom promotion and distribution, behaviour change and communication, voluntary counseling and testing (VCT), challenges in home care, comparative costs, adolescents and breast feeding and mother-to-childtransmission (MTCT). The performance audit (UNAIDS, 1998) was based on the outcome of various workshops held with internal and external stakeholders. The gap analysis was performed, also based on the principles described by UNAIDS (1998). The following dimensions were analysed: the role of the AIDS Council in relation to the subdistrict HIV/AIDS intersectoral committees, nutrition support and a supplementary feeding scheme, advocacy for healthy living and mother-to-child-transmission (MTCT). The following concluding statements, with reference to the response analysis, are relevant:

- The best practice examples highlighted key intervention areas for the HIV/AIDS epidemic/pandemic and spelled out lessons that have been learnt. It reiterates the importance of government commitment and intersectoral collaboration at all levels of society. It also highlights the importance of participation by stakeholders, especially people living with
AIDS (PWAs). Inclusion of the latter is one of the government's principles in HIV/AIDS and STI prevention, treatment and care.

- Interventions that have been proven to change behaviour, reduce the risk of HIV transmission and are cost-effective include: making STI care readily available and affordable; promoting and distributing condoms; changing behaviour through communication by utilizing the mass media and peer education: making available voluntary testing and counseling services; ensuring safe blood supplies and reducing/preventing transmission from mother to child (Greater Johannesburg Metropolitan Council, 1999:20-21).

- $\quad$ Best practice also indicated sufficient proof that syndromic management reduces the spread of HIV/ AIDS, and that periodic presumptive treatment, combined with preventive education and syndromic management of symptomatic women, is a viable option for STI service delivery in a population of high risk women (Neilsen \& Ballard, 1999: 27-29).

- $\quad$ Serious issues regarding home-based care have to be considered, especially those related to coverage, financial matters and a support structure. The youth as a group requires targeted intervention because of the high levels of infection among them. Again, lessons learnt indicate that intervention should happen before the youth become sexually active. Lastly, consideration should be given to the efficiency gains of targeted interventions versus a very broad approach (Wilson, 2000).

- General overlap and trends were noted among the strengths, weaknesses, opportunities and threats as identified by the external and internal stakeholders during the performance audit. An important aspect for consideration in the strategy was the role played by the AIDS Council in relation to the intersectoral committees. The various STI, TB, VCT, MTCT services, distribution of condoms and home based care were identified as opportunities and priorities and have been included in the strategy.

- The following gaps were identified: the role of the AIDS Council in relation to the sub-district HIV/ AIDS intersectoral committees; concerns regarding the need for a supplementary feeding scheme; the lack of congruency between national and provincial policies regarding preventative interventions, such as PAP-smears and support to mothers receiving treatment for the prevention of MTCT.

\section{A strategy for the management of HIV/AIDS in the health sector of the city of Johannesburg}

The strategy was formulated (refer to figure one), focusing 
on the purpose of the strategy and the various objectives and dimensions of the strategy, key performance indicators and leading positions (stakeholders):

- To lead and facilitate in intersectoral collaboration

- To strengthen primary health care services to provide comprehensive community-based care

- Prevention of new infections

- Community mobilization towards prevention, non discrimination and non stigmatization

- Empowerment of the health sector to deal with the AIDS epidemic/pandemic.

\section{Conclusion}

The objective of this study was to explore and describe a strategy for the management of HIV/AIDS by the health sector of the city of Johannesburg. The research was based on the UNAIDS (1998) Guide to the strategic planning process for a national response to HIV/AIDS. A strategy for the management of HIV/AIDS by the health sector of the city of Johannesburg was formulated and was confirmed as valid with reference to technically soundness, feasibility and perceived affordability.

\section{Limitations}

The limitations of the study are:

- Limited time frames and work pressure were experienced impacting on participants' response to attend the consultative workshops

- The Gauteng Provincial Health Department did not respond to any of the invitations

- The study did not include the process of resource mobilization recommended by UNAIDS (1998).

- $\quad$ The UNAIDS (1998) guide recommends field visits to be paid to external stakeholders during the response analysis. The performance audit was conducted by means of workshops with internal and external stakeholders. Thus the audit of the response was limited to stakeholders who participated in the workshops.

\section{Recommendations}

The following recommendations are made:

- Implementation and evaluation of the strategy, with appropriate resource mobilization to achieve the objectives within given resources allocated

- Empowerment of staff responsible for the implementation of the strategy

- The establishment of a monitoring committee to monitor and evaluate the implementation of the strategy and the health sector's progress towards the key performance indicators stipulated in the strategy and time frames indicated

- An impact analysis be conducted to determine the impact of the strategy on the key performance indicators, on resources such as human, financial, goods and services, and on the community.

\section{Acknowledgements}

Sincere gratitude goes to the Health Department of the City of Johannesburg for permission to conduct this study. A special word of thanks goes to the internal and external stakeholders who participated in the workshops and interviews.

\section{References}

AIDS DIRECTORATE 2000: Our AIDS epidemic. Caring for people with HIV/AIDS. Johannesburg: Gauteng AIDS Directorate.

BENENSON, AS 1995: Control of communicable diseases manual. Washington D C: American Public Health Association.

BOOYENS, SW 1998: Dimensions of Nursing Management; second edition. Cape Town: Juta.

BUCH, E 2000: Greater Johannesburg Metropolitan Council "Igoli 2010" project. Sector report: Health Services. Pretoria: University of Pretoria.

BURNS, N \& GROVE, 2001: The Practice of Nursing Research. Conduct, Critique \& Utilization; fourth edition. Philadelphia: WB Saunders.

BRINK, HI 1996: Fundamentals of Research Methodology for Health Care Professionals. Landsdowne: Juta.

CITY OF JOHANNESBURG, 2001: City development plan 2001/2002. Johannesburg: City of Johannesburg

DEMOCRATICNURSING ORGANISATIONOFSOUTH AFRICA (DENOSA) 1998: Position statements. Ethical standards for nurse researchers. Pretoria: DENOSA.

DEPARTMENT OF HEALTH 2000a: HIV/AIDS policy guideline: Prevention of mother-to-child-transmission and management of HIV positive pregnant women. South Africa: Department of Health.

DEPARTMENT OF HEALTH 2000b: HIV/AIDS/STD strategic plan for South Africa 2000-2005. Pretoria: Department of Health.

DEPARTMENT OF HEAITH 2000c: HIV/AIDS policy guideline: Testing for HIV. South Africa: Department of Health.

DEPARTMENT OF HEALTH 201a: National HIV and syphilis sero-prevalence survey of women attending public antenatal clinics in South Africa. 2000. Pretoria: Directorate: Health Systems Research \& Epidemiology.

DEPARTMENT OF HEALTH $2001 \mathrm{~b}$ : Protocol for providing a comprehensive package of care for the prevention of 
mother-to-child-transmission of HIV in South Africa. (Draft version 5 May 20(01). Pretoria: Department of Health.

DRYSDAI,E, S 200I: AIISS brief for sectoral planners and managers. Health sector. HEARD-Natal. Health Economics and HIV/AIIDS Research division (HEARD).

EDUCATION ANI) TRAININ(; UNIT 2001: HIV/AIDS campaign. A campaign manual for the Alliance and MIDM. Johannesburg: Education and Training Unit.

EVION, C; AIILEN, D; CONWAY,S; GRIMWOOD, A; HARI EY, B; HAUSI .ER, H; NEII SEN, (; \& SANNF, I 2(M): HIV/AIISS policy guideline: Prevention and treatment of opportunistic and HIV related diseases in adults. South Africa: Department of Health.

FIOYD, I \& SIMON, J 1999: The partnership against AIDS in action. How can I make a difference? Translating the Gauteng AIDS strategy into local inter-sectoral programmes. Johannesburg: Gauteng AIDS Directorate.

FLOYD, I \& MOI EKWA, S 2(KO): The partnership against AIDS in action. Annual report of the Gauteng AIDS programme 1999/2000. Johannesburg: Gauteng Provincial Government.

GAUTENG AIDS DIRECTORATE 1999a: AIDS strategy. Together we will make a difference to our future. Johannesburg: Department of Health.

GAUTENG AIDS DIRECTORATE 1999b: Claiming longer, healthier lives and death with dignity. Johannesburg: Gauteng Provincial Govermment, Department of Health.

(;AUTENG AIISS DIRECTORATE 19\%\%: The Gauteng five year AIDS strategy. Johannesburg: Gauteng AIDS Directorate.

GAUTENG AIDS DIRECTORATE 2002: AIDS care in Gauteng. Johannesburg: Gauteng AIDS Directorate.

(;AUTENG PROVINCIAI (,OVERNMENT 2001: Gauteng AIDS Programme annual report: $20(0) / 20(0)$ l. Johannesburg: Gauteng Provincial Government.

GRFAIERJOHANNESBURG METROPI ITANCOUNCII 2002: The new structures through which the city can deliver a more efticient and affordable service. Johannesburg: Greater Johannesburg Metropolitan Council.

HARI.EY,B 2000: Treating HIV-positive patients in the primary care setting. AIDS SCAN (2) June/ July 2000.

INTERSECTORAL AIDS PRO(;RAMME 2001: Gauteng AIDS programme annual report 20(0)-2001. Johannesburg: The AIDS Media Unit.

INTERSECTORAI AIDS UNIT 2(M)I: The Gauteng AIDS plan 2001-2001. Johaunesburg: Gauteng Provincial Government.
KARIM,Q; TARANTOI AD; ASSY, E \& MOXIV, R 1997: Government responses to HIV/AIDS in Africa: What have we learnt? AIISS (B) 1997: 143-149.

JOHANNESBURG; HIV MANAGEMENT SERVICES 1998: The impact of the HIV/AIDS epidemic on the Gauteng Provincial Government as employer: Report to the Gauteng Provincial Service Commission. Johannesburg: HIV Management Services (Pty) L.td.

I,YNN, MR 1986: Determination and quantification of content validity. Nursing Research. 35 (6), November-December 1986: 382-385.

MUI.IER, ME 2002: Nursing Dynamics; third edition. Sandown: Heinemann.

NEII SEN, G \& BAI.IARD, RS 1999: STD interventions for HIV/AIDS control in Africa. Occupational Health SA. Nov/Dec 1999:27-29.

SMART, R 2001: HIV/AIDS in the workplace. Gauteng: The AIDS I irectorate: Gauteng Department of Health.

South African Institute for Medical Research 2000: HIV/ RPR surveillance report amongst STD clinic attenders, January - June 2000. Johannesburg: STD Reference Centre.

SOUTH AFRICA (Republic) 1977: Health Act (no. 63 of 1977, as amended). Pretoria: State Press.

SOUTH AFRICA (Republic) 1997: White paper for the Transformation of the Health System in South Africa. Notice 667 of 1997. Pretoria: Government Printer.

SOUTH AFRICA (Republic) 2001: The National Health Bill. Pretoria: State Press.

THOMSON, S (Editor) 1997: Nurse Teachers as Researchers. A Reflective Approach. London: Arnold Publishers.

UNAIDS 1998: Guide to the strategic planning for a national response to HIV/AIDS. Modules: Introductory and 1-4. Best practice collection. Key material. Geneva: UNAIDS Information Centre.

WII SON, I) 2000: Planning, managing \& evaluating community AIDS/STD programmes. (Overhead slides. Obtained at the Thusano School of Public Health on 20 November 2000). Pretoria. Thusano School of Public Health.

WORID BANK 1999: Intensifying action against HIV/ AIDS in Africa. Responding to a development crisis. N.W. Washington D.C: World Bank. 


\section{TOLEAD AND FACILITATE INTERSECTORAL COLI_ABORATION}

\begin{tabular}{|c|c|c|c|c|}
\hline VES & STRATEGY & $\begin{array}{c}\text { KEY } \\
\text { PERFORMANCE } \\
\text { INDICATORS }\end{array}$ & $\begin{array}{c}\text { TME } \\
\text { FRAME }\end{array}$ & LEAD POSITIONS \\
\hline $\begin{array}{l}\text { nd interde- } \\
\text { AIDS com- }\end{array}$ & $\begin{array}{l}\text { - Integrate health programmes and occupa- } \\
\text { tional health in HIV/AIDS and STI co- } \\
\text { ordinating committee to develop programme } \\
\text { specific policies. } \\
\text { - Involve all sectors in Council in fight against } \\
\text { AIDS including utilities, agencies and } \\
\text { corporatised entities. }\end{array}$ & $\begin{array}{l}\text { - Clear defined roles } \\
\text { and Intrasectoral plans } \\
\text { - Sectoral AIDS plans }\end{array}$ & $\begin{array}{l}-2004 \\
-100 \% \text { by } \\
2005\end{array}$ & $\begin{array}{l}\text { Director: Health Services and deputy } \\
\text { and STI. } \\
\text { - Director: Health Services and deputy } \\
\text { and STI. }\end{array}$ \\
\hline $\begin{array}{l}\text { sectoral col- } \\
\text { ensure the } \\
\text { of partner- } \\
\text { vention, care } \\
\text { etworks. }\end{array}$ & $\begin{array}{l}\text { - Build capacity of staff to manage AIDS pro- } \\
\text { grammes. } \\
\text { - Establish HIV/AIDS intersectoral commit- } \\
\text { tees in all subdistricts and develop subdis- } \\
\text { trict operational plans. } \\
\text { - Mapping of at-risk communities per sub- } \\
\text { district. } \\
\text { - Develop link between subdistrict } \\
\text { intersectoral committees and AIDS Council. } \\
\text { - Develop network referral plan with stand- } \\
\text { ardised communication protocols and forms } \\
\text { adopted and implemented by all stakeholders. } \\
\text { - Liaise with regional provincial office to de- } \\
\text { volve funding and monitoring of NGOs } \\
\text { - Develop and implement NGO monitoring } \\
\text { plan. }\end{array}$ & $\begin{array}{l}\text { - No of management } \\
\text { staff trained } \\
\text { - Subdistrict opera- } \\
\text { tional plans } \\
\text { - Database of at-risk } \\
\text { communities } \\
\text { - Terms of reference } \\
\text { - Referral plan } \\
\text { - Evaluation reports of } \\
\text { NGOs } \\
\text { - Standard protocols }\end{array}$ & $\begin{array}{l}\text { - } \quad 95 \% \text { by } \\
2005 \\
\text { - } 2004 \\
\text { - } 2004 \\
\text { - } 2004 \\
\text { - } 2004 \\
\text { Implementa- } \\
\text { tion incre- } \\
\text { mentally } \\
\text { - } 2004 \\
\text { - } 2004\end{array}$ & $\begin{array}{l}\text { - Deputy director HIV/AIDS and STI a } \\
\text { PHC. } \\
\text { - Deputy director HIV/AIDS and STI an } \\
\text { directors. } \\
\text { - Subdistrict HIV/AIDS co-ordinator an } \\
\text { district Intersectoral AIDS Committee. } \\
\text { - Director: Health Services and deputy dire } \\
\text { and STI. } \\
\text { - Deputy director: HIV/AIDS and STI, ar } \\
\text { directors and stakeholders. } \\
\text { - Director: Health Services and deputy c } \\
\text { and STI. } \\
\text { - Deputy director: HIV/AIDS and STI and } \\
\text { istration. }\end{array}$ \\
\hline
\end{tabular}




\section{TOSTRENGTHEN PRIMARY HEALTH CARESERVICES TOPROVIDECOMPREHENSIVECOMMUNITY-BASEDCARE}

\begin{tabular}{|c|c|c|c|c|}
\hline ETIVES & STRATEGY & $\begin{array}{c}\text { KEY } \\
\text { PERFORMANCE } \\
\text { INDICATORS } \\
\end{array}$ & $\begin{array}{l}\text { TINE } \\
\text { FRAME }\end{array}$ & LEAD POSITION \\
\hline $\begin{array}{l}\text { te health profes- } \\
\text { provide HIV/ } \\
\text { across the care }\end{array}$ & $\begin{array}{l}\text { - Develop local policy based on provincial } \\
\text { guidelines, i.e. medical tests, PEM scheme etc. } \\
\text { - On-going capacitation of staff with regard } \\
\text { to diagnosis, stage assessment, medical care, } \\
\text { counselling, treatment of opportunistic infec- } \\
\text { tions and palliative care. } \\
\text { - Provision of AIDS adult and paediatric treat- } \\
\text { ment in all clinics. } \\
\text { - Strengthen TB control programme through } \\
\text { staff capacitation and DOTS programme. } \\
\text { - Establish expert medical clinician support } \\
\text { to health facilities. }\end{array}$ & $\begin{array}{l}\text { - Policy } \\
\text { - No of staff trained } \\
\text { and no of in-service } \\
\text { training sessions } \\
\text { - Basket of services } \\
\text { per clinic. } \\
\text { - Cure rate and \% of } \\
\text { patient on community } \\
\text { DOTS. } \\
\text { - No of enquiries. }\end{array}$ & $\begin{array}{l}\cdot 2004 \\
\cdot 2004 \\
\text { Ongoing } \\
-100 \% \text { by } \\
2005 \\
-80 \% \\
-2004 \text { Incre- } \\
\text { mentally }\end{array}$ & $\begin{array}{l}\text { - Deputy director: PHC. } \\
\text { - Deputy director: PHC. } \\
\text { - Director: Health Services and deput } \\
\text { and STI and subdistrict health directors } \\
\text { - Deputy director: PHC. } \\
\text { - Deputy director: PHC. }\end{array}$ \\
\hline $\begin{array}{l}\text { eventative serv- } \\
\text { lote positive liv- } \\
\text { V. }\end{array}$ & $\begin{array}{l}\text { - Develop local policy for provision of pre- } \\
\text { ventative services e.g. TB prophylaxis, PAP } \\
\text { smears and influenza vaccination, blood tests, } \\
\text { Diflucan Partnership Programme etc. } \\
\text { - Provide prophylactic treatment for PWAS } \\
\text { according to policy. }\end{array}$ & $\begin{array}{l}\text { - Policy available } \\
\text { - Prophylactic drugs } \\
\text { utilisation and no of } \\
\text { PAP smears and influ- } \\
\text { enza vaccine campaign } \\
\text { results. }\end{array}$ & $\begin{array}{l}-2004 \\
-2005 \\
\text { Incremental } \\
\text { implementa- } \\
\text { tion based on } \\
\text { resources }\end{array}$ & $\begin{array}{l}\text { - Deputy director: HIV/AIDS and ST } \\
\text { Communicable Diseases, and deputy d } \\
\text { district health directors. } \\
\text { - Director: Health Services and deput } \\
\text { and STI and subdistrict health directors }\end{array}$ \\
\hline $\begin{array}{l}\text { comprehensive } \\
\text { etwork. }\end{array}$ & - (Refer Intersectoral Collaboration) & & & \\
\hline
\end{tabular}




\begin{tabular}{|c|c|c|c|c|}
\hline tri & $\begin{array}{l}\text { - Develop and implement local district and } \\
\text { palliative care policy with support protocols } \\
\text { for home- based care (HBC). } \\
\text { - Develop and implement policy for the inte- } \\
\text { gration of community DOTS programme and } \\
\text { HBC. } \\
\text { - Ensure and monitor the delivery of quality } \\
\text { HBC. }\end{array}$ & $\begin{array}{l}\text { - Policy and protocols } \\
\text { available. } \\
\text { - \% increase combined } \\
\text { services utilised. } \\
\text { - Standards for HBC }\end{array}$ & $\begin{array}{l}\cdot 2004 \\
\cdot 2004 \\
\text { - } 2004\end{array}$ & $\begin{array}{l}\text { - Health core administration and provi } \\
\text { and AIDS directorate. } \\
\text { - Deputy director:HIV/AIDS and STI } \\
\text { Communicable Diseases and deputy dir } \\
\text { district health directors } \\
\text { - Health Core administration and prov } \\
\text { and AIDS directorate. }\end{array}$ \\
\hline ess to counsel- & $\begin{array}{l}\text { - Training of staff to strengthen councelling } \\
\text { capacity. } \\
\text { - Develop counselling network with } \\
\text { stakeholders (refer Intersectoral Collaboration) }\end{array}$ & $\begin{array}{l}\text { - } 95 \% \text { of staff to be ca- } \\
\text { pacitated } \\
\text { - Annual } \% \text { increase in } \\
\text { access to counselling } \\
\text { services. }\end{array}$ & $\begin{array}{l}-2005 \\
-\quad \text { Ongoing }\end{array}$ & $\begin{array}{l}\text { - Deputy director: PHC and subdistrict } \\
\text { - Deputy director: HIV/AIDS and STI : } \\
\text { rectors. }\end{array}$ \\
\hline CTIVES & STRATEGY & $\begin{array}{l}\text { ENTIONOF NEW INFEC } \\
\text { KEY PERFORMANCE } \\
\text { INDICATORS }\end{array}$ & $\begin{array}{l}\text { TME } \\
\text { FRAME }\end{array}$ & LEAD POSITIONS \\
\hline $\begin{array}{l}\text { number of sexu- } \\
\text { itted infections }\end{array}$ & $\begin{array}{l}\text { - Annual evaluation of STI servi-ces by utili- } \\
\text { sation of DISCA tool; redressing of issues } \\
\text { identified. } \\
\text { - Improve partner notification. } \\
\text { - Facilitate ongoing training of professional } \\
\text { nurses with regard to syndromic management } \\
\text { of STIs. }\end{array}$ & $\begin{array}{l}\text { - Annual report: } \\
\text { DISCA evalua-tion. } \\
\text { - \% Increase in no of } \\
\text { partner notifica-tion } \\
\text { slips issued and re- } \\
\text { turned. } \\
\text { - No of staff trained. }\end{array}$ & - Ongoing & $\begin{array}{l}\text { - Deputy director: HIV/AIDS and STI } \\
\text { tional managers. } \\
\text { - Professional nurses and health promo } \\
\text { - Deputy director: PHC and deputy dire } \\
\text { STI. }\end{array}$ \\
\hline $\begin{array}{l}\text { f vulnerability } \\
\text { pulations. }\end{array}$ & $\begin{array}{l}\text {-Youth } \\
\text { - Implement peer education life skills training } \\
\text { to youth out of school and in tertiary training } \\
\text { institutions in partnership with NGOs, train- } \\
\text { ing sector, CBOs and religious sector. }\end{array}$ & $\begin{array}{l}\text { - No of peer educators } \\
\text { trained. }\end{array}$ & $\begin{array}{l}\text { - Start imple- } \\
\text { m e n t a t i o n } \\
2003\end{array}$ & $\begin{array}{l}\text { - Deputy director: HIV/AIDS and STI } \\
\text { AIDS and STI co-ordinators. }\end{array}$ \\
\hline
\end{tabular}


- Establish youth-friendly health services.

Sex workers/marginalised communities/singlesex hostels/migrant labourers.

- Investigate and implement additional specific outreach programmes based on PSG model and other models in partnership (including research institutions ) in high-risk areas.

\section{Women}

- Arrange empowerment workshops and special programmes for women with regard to violence, taboos, etc.

n prevention of hild transmiselling ( VCT) nable early diIV and preveninfections.

- Assist with the monitoring of mothers in pilot programmes.

- Promote VCT amongst women of childbearing age to enable informed decisions regarding reproductive health.

- Provide training with regard to nutritional counselling including lactation management, breast feeding and HIV .

- Develop policy with regard to provision of breast milk substitutes.

- Increase accessibility to VCT within services and communities.
- Prioritise access to VCT or counselling to clinics offering antenatal care. testing.
- Teenage pregnancy rate. report, i.e. no of condoms distributed.

- No of workshops and attendance. No of abused women treated at clinics.

\section{- $100 \%$ by 2004}

- 2004

incremental-

ly

- 2004

- Reports as required

- 2004

- No of HIV blood tests done

- No of staff trained

- 2004 (based on access to testing facilities

- 2004 $100 \%$ staff by 2005

- Policy document
Subdistrict health directors.

- Deputy director: HIV/AIDS and STI

AIDS and STI co-ordinators, NGOs.

- Subdistrict HIV/AIDS and STI co-ord motion/ NGOs.

- Deputy director: HIV/AIDS and STI a directors

- Professional nurses and health promo

- Deputy director: PHC.

- Deputy director: PHC.
- $20 \%$ in-

Subdistrict health directors and AIDS crease by tee.

2004 - Accessibility to HIV -2004

- Subdistrict health directors 


\begin{tabular}{|c|c|c|c|c|}
\hline $\begin{array}{l}\text { ommunity-based } \\
\text { on of condoms. }\end{array}$ & $\begin{array}{l}\text { - Improve access to condoms in the commu- } \\
\text { nity, also after hours. }\end{array}$ & $\begin{array}{l}\text { - } \% \text { increase in no. of } \\
\text { condom distribution } \\
\text { points and no. of con- } \\
\text { doms provided after } \\
\text { hours. } \% \text { increase in } \\
\text { con-doms distributed. }\end{array}$ & $\begin{array}{l}\text { Ongoing } \\
\text { based on } \\
\text { policy. }\end{array}$ & $\begin{array}{l}\text { - Subdistrict health directors and subdis } \\
\text { committee, and subdistrict HIV/AIDS }\end{array}$ \\
\hline Workplace pro- & $\begin{array}{l}\text { - Support HR: CoJ in develop-ment of } \\
\text { workplace programme. } \\
\text { - Support private sector in development of } \\
\text { workplace programmes. } \\
\text { - Train workplace peer educators. } \\
\text { - Establish sustainable condom distribution. }\end{array}$ & $\begin{array}{l}\text { - Progress report: CoJ } \\
\text { Workplace programme } \\
\text { - No of workplace pro- } \\
\text { grammes established. } \\
\text { - No of peer educators } \\
\text { trained. } \\
\text { - No of condoms dis- } \\
\text { tributed. }\end{array}$ & $\begin{array}{l}- \text { Ongoing } \\
\text { tally Increme- }\end{array}$ & $\begin{array}{l}\text { - Subdistrict HIV/AIDS and STI co-o. } \\
\text { - Subdistrict HIV/AIDS and STI co-o }\end{array}$ \\
\hline & \multicolumn{4}{|c|}{ COMMUNITY MOBILIZATIONTOWARDS PREVENTION. NON-DISCRIMINATIONANDNON-STIGMLTISATION } \\
\hline JECTIVES & STRATEGY & $\begin{array}{l}\text { KEY PERFORMANCE } \\
\text { INDICATORS }\end{array}$ & $\begin{array}{l}\text { TIME } \\
\text { FRAME }\end{array}$ & LEAD POSITION \\
\hline $\begin{array}{l}\text { leadership sup- } \\
\text { understanding of } \\
\text { gramme. }\end{array}$ & $\begin{array}{l}\text { - Capacity building amongst leadership to } \\
\text { elicit appropriate visible support and alloca- } \\
\text { tion of resources, e.g. political, religious sec- } \\
\text { tor, youth and other groups. }\end{array}$ & $\begin{array}{l}\text { - Leadership participa- } \\
\text { tion and support. } \\
\text { - Funding of HIV/AIDS } \\
\text { programme. }\end{array}$ & $\begin{array}{l}\text { - } 100 \% \text { politi- } \\
\text { cal by } 2004 . \\
\text { Others as net- } \\
\text { work devel- } \\
\text { ops }\end{array}$ & $\begin{array}{l}\text { - Director: Health Services and depu } \\
\text { and STI and subdistrict HIV/AIDS and }\end{array}$ \\
\hline $\begin{array}{l}\text { communities to } \\
\text { sexual behaviour } \\
\text { upport those in- } \\
\text { affected by HIV/ }\end{array}$ & $\begin{array}{l}\text { - Arrange special campaigns according to } \\
\text { calendar, e.g. Valentines day, condom week, } \\
\text { candle light memorial, Youth day, Schools } \\
\text { AIDS week. Women's day. } \\
\text { - Support any significant event, e.g. sports } \\
\text { days, cultural and social events. } \\
\text { - Campaigns for targeted groups, e.g Youth. }\end{array}$ & $\begin{array}{l}\text { - Campaign re-ports: } \\
\text { No of people reached, } \\
\text { no of condoms distrib- } \\
\text { uted. Mini-mum accord- } \\
\text { ing to city development } \\
\text { plan. }\end{array}$ & - Ongoing & $\begin{array}{l}\text { - Deputy director: HIV/AIDS and ST } \\
\text { rectors. }\end{array}$ \\
\hline
\end{tabular}




\begin{tabular}{|c|c|c|c|c|}
\hline $\begin{array}{l}\text { areness through } \\
\text { ertising. }\end{array}$ & $\begin{array}{l}\text { Display and distribute HIV/AIDS posters, } \\
\text { pamphlets and condoms in all council build- } \\
\text { ings and at information desks and pay points } \\
\text { in the city. } \\
\text { - Utilise the media and publicity tools to com- } \\
\text { municate with the community. }\end{array}$ & $\begin{array}{l}\text { - No of condoms sup- } \\
\text { plied and pamphlets } \\
\text { distributed. } \\
\text { - Newspaper clippings } \\
\text { and publicity tools pro- } \\
\text { duced. }\end{array}$ & $\begin{array}{l}\text { - } 100 \% \text { coun- } \\
\text { cil buildings } \\
2004 . \\
\text { - Ongoing } \\
\text { according to } \\
\text { operational } \\
\text { plans. }\end{array}$ & $\begin{array}{l}\text { - Deputy director: HIV/AIDS and ST] } \\
\text { - Deputy Director HIV/AIDS and STI } \\
\text { cations. Marketing and Tourism. }\end{array}$ \\
\hline $\begin{array}{l}\text { the root causes of } \\
\text { S. STIs and TB. }\end{array}$ & $\begin{array}{l}\text { - Participate in poverty alleviation, crime pre- } \\
\text { vention and skills development programmes, } \\
\text { e.g. ABET. }\end{array}$ & $\begin{array}{l}\text { - City develop-ment } \\
\text { plan 2002-2030. }\end{array}$ & - On-going & - Director: Health Services and all he \\
\hline
\end{tabular}

\section{CAPACITATIONOF HE ALTH SECTOR TODEAL WITH AIDSPANDEMIC}

\begin{tabular}{|c|c|c|c|c|}
\hline ECTIVES & STRATEGY & $\begin{array}{l}\text { KEY PERFORMANCE } \\
\text { INDICATORS }\end{array}$ & $\begin{array}{c}\text { TME } \\
\text { FRAME }\end{array}$ & LEAD POSITIO \\
\hline $\begin{array}{l}\text { stems to deal } \\
\text { asing patient }\end{array}$ & $\begin{array}{l}\text { - Functional and structural integration with } \\
\text { Gauteng Regional Health Authority } \\
\text { - Investigate best practice and develop stand- } \\
\text { ard operating procedures to deal with increas- } \\
\text { ing no of patients. } \\
\text { - Develop monitoring and evaluation sys- } \\
\text { tems in line with minimum data set and local } \\
\text { needs. }\end{array}$ & $\begin{array}{l}\text { - As per City Develop- } \\
\text { ment Plan } \\
\text { - Standard operating } \\
\text { procedures } \\
\text { - Data reported }\end{array}$ & $\begin{array}{l}2004 \\
\text { In cre m e n - } \\
\text { tally } \\
-2004 \\
-2004\end{array}$ & $\begin{array}{l}\text { - Director: Health Services } \\
\text { - Deputy director: HIV/AIDS and S } \\
\text { Communicable Diseases and deputy di } \\
\text { rector: HIS and subdistrict health dire } \\
\text { - Deputy director: HIS }\end{array}$ \\
\hline $\begin{array}{l}\text { alth sector work } \\
\text { amme. }\end{array}$ & $\begin{array}{l}\text { - Improve Post-Exposure Prophylaxis (PEP) } \\
\text { programme. } \\
\text { - Implement register for monitoring of TB in } \\
\text { the workplace. } \\
\text { - Develop dedicated employee assistance pro- } \\
\text { gramme for health workers to provide coun- } \\
\text { selling debriefing systems; address burnout. } \\
\text { INH prophylaxis for health worker PWAs. }\end{array}$ & $\begin{array}{l}\text { - PEP Monitoring Reg- } \\
\text { ister } \\
\text { - TB Register for staff } \\
\text { members } \\
\text { - Basket of services: } \\
\text { EAP and No of attend- } \\
\text { ance }\end{array}$ & $\begin{array}{l}\cdot 2004 \\
\cdot 2004 \\
\cdot 2004 \\
\text { Incremental }\end{array}$ & $\begin{array}{l}\text { - Deputy director: HIV/AIDS and ST] } \\
\text { Health. } \\
\text { - Assistant director: TB } \\
\text { - Deputy director:HIV/AIDS and STI } \\
\text { Health. }\end{array}$ \\
\hline
\end{tabular}

